\title{
THE DEVELOPMENT OF NEW METHOD OF PRODUCTION OF HEALTHY ICE-CREAM-SORBET OF FRUITS AND VEGETABLES WITH A RECORD BAS CONTENT
}

\author{
Raisa Pavlyuk \\ Department of Technology processing of fruits, vegetables and milk \\ Kharkov State University of Food Technology and Trade \\ 333 Klochkivska str., Kharkiv, Ukraine, 61051 \\ ktppom@ukr.net \\ Viktoriya Pogarska \\ Department of Technology processing of fruits, vegetables and milk \\ Kharkov State University of Food Technology and Trade \\ 333 Klochkivska str., Kharkiv, Ukraine, 61051 \\ Vadym Pavlyuk \\ Doctor of Physical and Mathematical Sciences, Professor \\ Department of Applied Mathematics and Information Technologies \\ Kharkiv Trade and Economics Institute of Kyiv National University of Trade and Economics \\ 8 Otakara Jarosha alley, Kharkiv, Ukraine, 61045 \\ Aleksey Pogarskiy \\ Department of Technology processing of fruits, vegetables and milk \\ Kharkov State University of Food Technology and Trade \\ 333 Klochkivska str., Kharkiv, Ukraine, 61051 \\ Iuliia Kakadii \\ Department of Technology processing of fruits, vegetables and milk \\ Kharkov State University of Food Technology and Trade \\ 333 Klochkivska str., Kharkiv, Ukraine, 61051 \\ ykakadiy@ukr.net \\ Tetyana Stukonozhenko \\ Department of Technology processing of fruits, vegetables and milk \\ Kharkov State University of Food Technology and Trade \\ 333 Klochkivska str., Kharkiv, Ukraine, 61051 \\ tasichkayo@gmail.com \\ Oleksandr Telenkov \\ The teacher of the highest category \\ Putivl College of Sumy National Agrarian University \\ 80 Lunocharskogo str., Putivl, Ukraine, 41500
}

\footnotetext{
Abstract

The aim of the work is to develop a new type of producing healthy fruit-vegetable ice-cream-sorbet with the record BAS content using fresh vegetables and fruits as raw materials (especially, berries: blackberry, cherry, apricots, sea buckthorn, fruits apples, lemons with zest, vegetables - spinach, olives, pumpkin) and innovative technological methods, such as cryogenic "shock freezing" and low temperature comminution.

There was offered and developed a new way of preparing healthy fruit-vegetable ice-cream-sorbet, based on using cryogenic "shock" freezing and fine-dyspersated comminution of vegetables and fruits as an innovative method of structure creation and getting sorbets with the record BAS content. The complex effect of these methods results in activation and extraction of hidden BAS from fruits and vegetables in the free form, and also in pectin transformation from the inactive form into the active one. A peculiarity of producing sorbets is the use of only natural ingredients (fruits, berries, vegetables) and also the absence of artificial food supplements (stabilizers, stiffeners, emulsifiers, synthetic coloring agents and so on). The new method allows to preserve vitamins and other BAS of initial raw materials completely in sorbets. At the same time it gives a possibility to extract from raw materials hidden inactive BAS forms, bound in nanocomplexes with biopolymers and mineral substances, into the free, easily-assimilated nanoform.
} 
The mass share of BAS in sorbets is 2,5...3,5 times more that in fresh fruits and vegetables that is controlled by standard chemical methods. At the same time the new method allows to extract and transform into the soluble form pectin substances that are in fruits and vegetables in the inactive hidden form more completely (by $70 \%$ ). The mass share of soluble pectin in sorbets is $3,0 \ldots 5,0$ times more than in fresh raw materials.

The following fruits and vegetables were chosen at preparing sorbets: apples, blackberry, cherry, apricots, sea buckthorn, pumpkin, spinach, olives, lemon with zest. They are known for their treating-prophylactic properties and first of all favor strengthening of the human organism's immunity.

The recipes of healthy sorbets were developed - 3 types of fruit-vegetable ice-cream with chlorophyll-containing, carotene-containing and anthocyan-containing fruits and vegetables. Natural fruit-vegetable raw materials at preparing ice-cream-sorbets act as five in one: a source of BAS, stiffeners, structure-creators, coloring agents and aromatizers. New types of sorbets are in the nanosize form and exceed analogues by BAS. Technological regimes of producing ice-cream-sorbets are developed at the stand semi-industrial equipment.

Keywords: cryogenic processing, BAS, fruits and vegetables, fine-dyspersated comminution, healthy products, sorbets, extraction of hidden BAS, pectin activation. Aleksey Pogarskiy, Iuliia Kakadii, Tetyana Stukonozhenko, Oleksandr Telenkov

\section{Introduction}

Among healthy products of fruits, berries vegetables, an important place is occupied by sorbets that are one of ice-cream types, popular among the population of different world countries [1-3]. Sorbets are traditionally produced of fresh fruit-vegetable raw materials and also puree, juices without using milk [1-3]. A shortcoming at producing sorbets is the use of artificial food supplements (stabilizers, stiffeners, emulsifiers, synthetic coloring agents and so on) [4-6]. Freezing and storage of sorbets take place at $-18{ }^{\circ} \mathrm{C}$. This method allows to get high-quality sorbets, which storage term is 10 months $[6,7]$. But the essential amount of BAS $(20-50 \%)$ is lost at defrost and storage. That is why a shortcoming of sorbets is a low content of vitamins and other BAS ad also the presence of artificial components, negatively influencing the human organism. So, international practice in the last 10 years changed requirements to ice-cream of both consumers and companies that produce and realize it. The main requirement to ice-cream is the maximal naturalness and also the presence of components, favoring health strengthening, in its composition [8,9].

It is known, that one of prospective directions of processing fruits, berries, vegetables and other products is cryogenic processing of raw materials using cryogenic "shock" freezing and cryogenic comminution [10]. This method provides the highest degree of preserving vitamins and other BAS [11]. It was established, that the higher speed of freezing vegetable products, the better vitamins and other BAS are preserved, and also the less losses of cellular juice at freezing and keeping the structure are [12].

But in Ukraine the cryogenic method didn't find the proper use for today. Cryogenic technologies are not developed, and biochemical, physical-chemical processes at freezing fruits, berries vegetables and at producing sorbets without using food admixtues, synthetic coloring agents and aromatizers are not studied. Results of fundamental and applied studies of the influence of cryogenic "shock" freezing and low-temperature fine-dyspersated comminution of fruits, berries and vegetables, obtained in Kharkiv state university of food and trade are an exclusion [12-14].

So, the aim of this work is to develop a new method of producing healthy fruit-vegetable ice-cream-sorbets with the record BAS content, using fresh vegetables and fruits as raw materials and innovative technological methods, such as cryogenic "shock freezing" and low temperature comminution. It allows to get sorbets of the healthy effect with the record content of biologically active substances without using different artificial food admixtures.

\section{Materials and Methods}

Fresh and frozen fruits and vegetables (blackberry Vernisazh), cherry (Griot Seridko), apple (Simirenko), lemon with zest (Lisbon), apricot (Chervonoschoky), sea buckthorn (Azhurna), spinach (Victoria), olives (Greek), pumpkin (Mustatny)) and new nanosorbets of fruit-vegetable raw materials were used in the work as research objects (Fig. 1, 2). 
For attaining this aim, the complex influence of cryodestruction and mechanoactivation on raw materials at fine-dyspersated comminution was used as an innovation at producing fruit-vegetable ice-cream-sorbet using the modern equipment for cryogenic "shock" freezing and fine-dyspersated comminution for activation and extraction of hidden Bas forms in the free easily-assimilated one [3].

Specialists of the department of technologies of processing fruits vegetables and milk of Kharkiv state university of food and trade (Ukraine) together with co-workers of Putyvl agrarian college (Ukraine) developed a new way of producing fruit-vegetable healthy nanosorbets of chlorophyll-containing, carotene-containing and anthocyan-containing vegetable raw materials using the method of deep cryogenic processing of vegetable raw materials, offered by the authors.

The experimental studies were conducted at Kharkiv state university of food and trade (KSUFT, Ukraine) at the department of technologies of processing fruits, vegetables and milk, in the experimental-research laboratory of "Innovative cryo- and nanotechnologies of vegetable supplements and healthy products" using the modern equipment (cryogenic fast-freezing apparatus, comminutor «Robot Coupe» (France), Low-temperature comminutor-activator «SIRMAN» (Italy)) for cryogenic "shock" freezing and fine-dyspersated comminution.

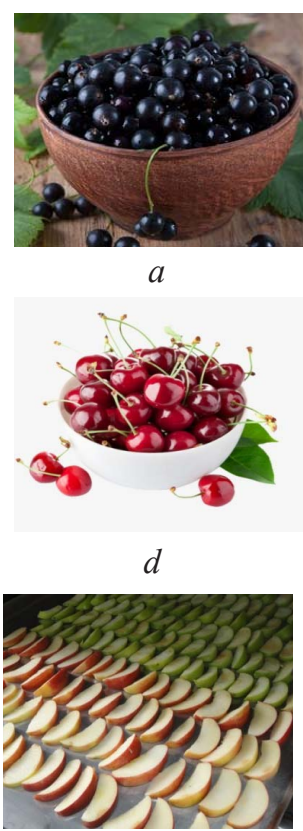

$g$

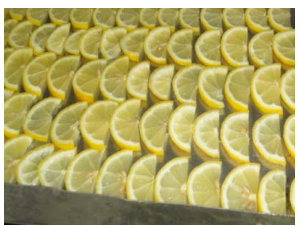

$j$

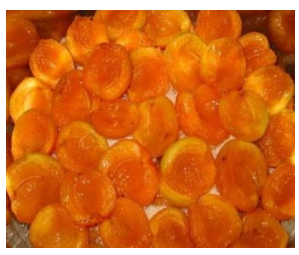

$m$

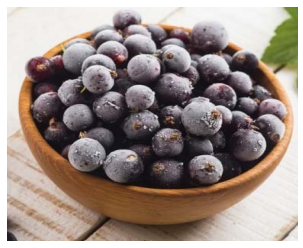

$b$

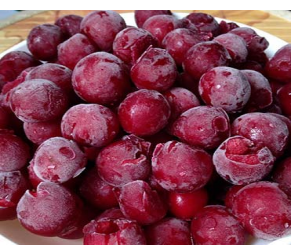

e

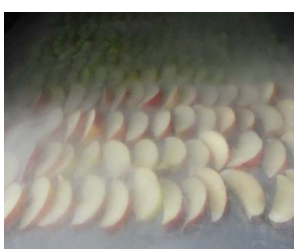

$h$

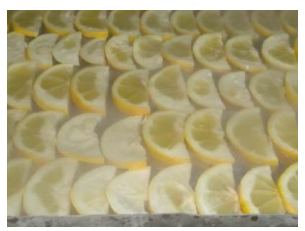

$k$

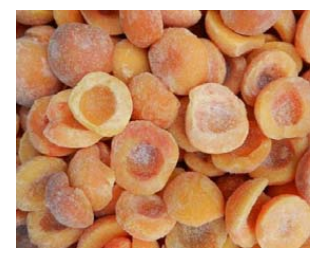

$n$

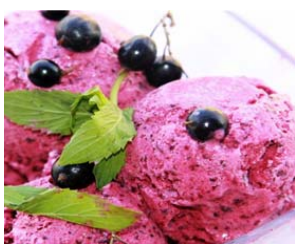

c

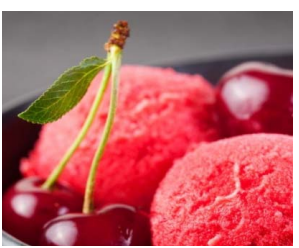

$f$

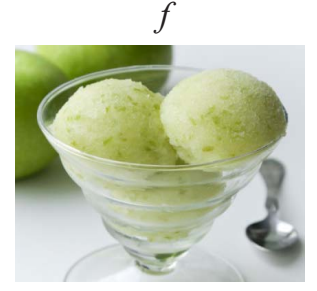

$i$

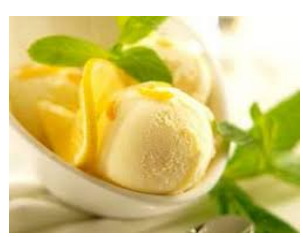

l

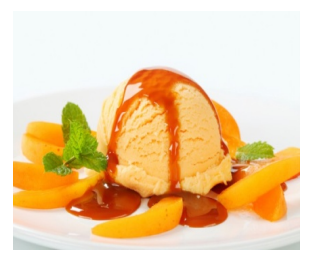

$o$

Fig. 1. Research objects: $a$ - fresh blackberry, $b$ - frozen blackberry, $c$ - nanosorbet of blackberry; $\mathrm{d}$ - fresh cherry, e - frozen cherry, $f$ - nanosorbet of cherry; $g$ - fresh apples, $h$ - frozen apples, $i$ - nanosorbet of apples; $j$ - fresh lemons, $k$ - frozen lemons, $l$ - anosorbets of lemons with zest; $m$ - fresh apricots, $n$ - frozen apricots, $o$ - nanosorbet of apricots 


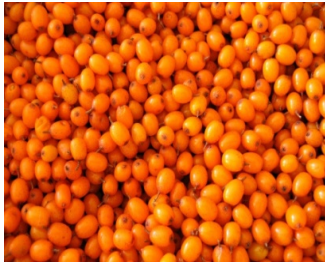

$a$

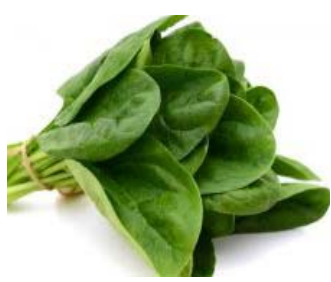

$d$

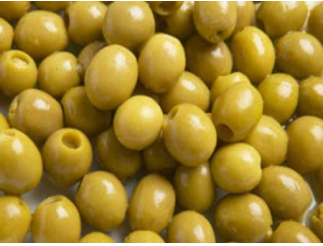

$g$

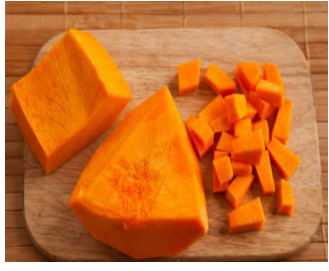

$j$

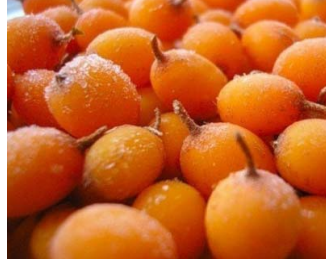

$b$

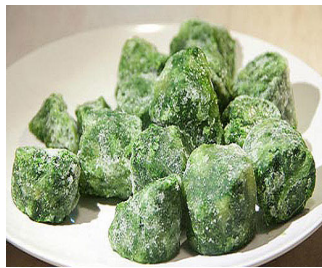

e

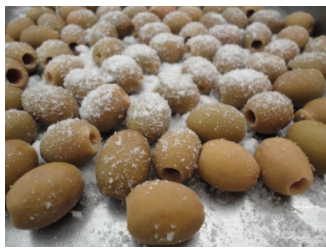

$h$

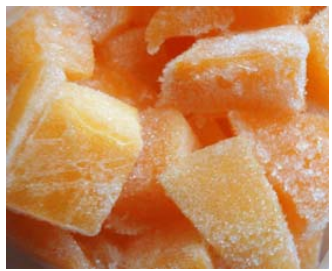

$k$

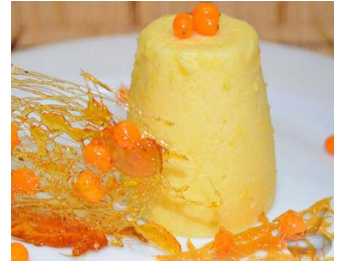

$c$

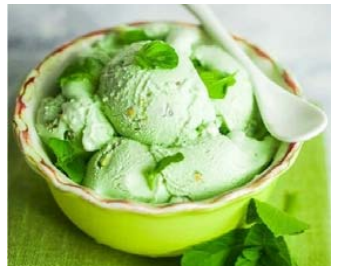

$f$

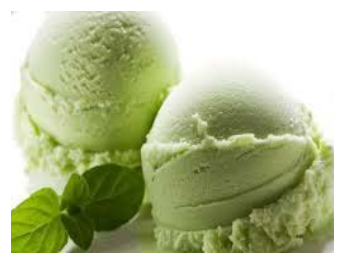

$i$

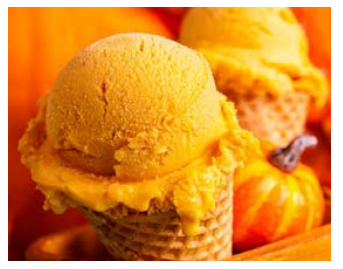

$l$

Fig. 2. Research objects: $a$ - fresh sea buckthorn, $b$ - frozen sea buckthorn, $c$ - nanosorbet of sea buckthorn, $d$ - fresh spinach, $e$ - frozen spinach, $f$ - nanosorbet of spinach; $g$ - olives, $h$ - frozen olives, $i$ - nanosorbet of olives; $j$ - fresh pumpkin, $k$ - frozen pumpkin, $l$ - nanosorbet of pumpkin

The model studies of the influence of cryogenic "shock" freezing were conducted in the fast-freezing experimental apparatus using the gas-like nitrogen as a cooling agent and inert liquid medium [13, 14]. The apparatus is intended for freezing products with a solid surface and liquid products, placed in a special package. The fast-freezing apparatus allows to vary a temperature within a freezing chamber within the diaposon from $-5^{\circ} \mathrm{C}$ to $-100^{\circ} \mathrm{C}$.

The work was realized the modern original equipment from the department of KSUFT for cryogenic freezing - program cryogenic "shock" freezer with liquid nitrogen as a cooling agent and liquid medium. At that the temperature in the freezing chamber was from $-60{ }^{\circ} \mathrm{C}$ to $-100{ }^{\circ} \mathrm{C}$. Fruits, vegetables, berries were frozen with different high speeds to different temperatures in epy product.

The use of this equipment allows to model technological processes for revealing methods of the maximal preservation of BAS and biopolymers of the vegetable raw materials. The obtained research results were used at developing nanotechnologies of producing new types of supplements and products of fruits, berries and vegetables, which quality by the BAS content exceeds the quality of the initial raw materials and one of products and supplements - analogues.

\section{1. Experimental procedures}

The quality by the content of main BAS (low-molecular phenol compounds, polyphenols, $\mathrm{L}$-ascorbic acid, anthocyans, $\beta$-carotene, chlorophylls a and $\mathrm{b}$, pectin, including soluble organic 
acids, protein) was determined in fresh and frozen vegetables and fruits (blackberry, cherry, apples, lemons with zest, apricots, sea buckthorn, spinach, olives, pumpkin) and new nonosorbets of the fruit-vegetable raw materials.

The control of biologically active substances (BAS) was determined by the following methods:

- Low-molecular phenol compounds (by rutin and chlorogenic acid separately), determined by the colorimetric method of Folin-Denis in recalculation by chlorogenic acid.

- Tanning substances (by tannin), determined by the titrometric method in recalculation by tannin. This method is based on an ability of tanning substances to oxidize in presence of an indigo carmine indicator.

- L-ascorbic acid, determined by the method of visual and potentiometric titration by the solution of 2,6-dichlorophenolindophenolate $\mathrm{Na}$.

- $\beta$-carotene, controlled by the colorimetric method of Mouri after extracting carotene from the product by an organic dissolvent and cleaning it from accompanied color substances using column chromatography.

- Anthocyans, determined by the colorimetric method, based on determining the mass concentration of color substances in coloring agents by comparing the coloration intensity of the control solution, prepared of Cobalt sulphate and the studied solution.

- Chlorophylls a and b, determined by the spectrophotomeric method in acetone extracts of experimental samples. The method is based on the difference of maximums in spectrums of chlorophyll absorption in the red zone.

- Pectin, the method is based on hydrolysis of pectin substances and precipitation of polygalacturonic acid as cellulose calcium pectate.

- Organic acids, the method is in removing free acids with water steam and further titration by alkaline. For transforming salts in free acids, orthophosphate acid is used. The amount of titrated volatile acids is recalculated for acetic acid.

- Protein, determine by the nitrogen-metric method (Kjeldahl) method, based on determining the amount of protein nitrogen, formed at destructing amino acids, included in the protein composition.

\section{Results}

The authors in this work offered to use cryogenic "shock" freezing and low-temperature fine-dyspersated comminution as a innovation at developing the new way of producing healthy nanoproducts «NatureSuperFood» (at the stage of introduction in production) - fruit-vegetable ice-creamsorbets of fruits, berries, vegetables. It gave a possibility to get new types of ice-cream-sorbets in the nanosize form with the record BAS content (2...3,5 times more than in the initial raw materials) and to exclude a necessity of using food supplements, traditionally included to the composition of sorbets.

There was offered and developed the new method of getting healthy products - fruit-vegetable ice-cream-sorbets of fruits, vegetables, berries - that allows to get products «NatureSuperFood» with unique characteristics. New types of products are in the easily-assimilated nanosize form and are remarkeable for the high content of natural biologically active substances ( $\mathrm{L}$ - ascorbic acid, $\beta$-carotene, chlorophylls a and $b$, phenol compounds, anthocyans, aromatic substances and other). The new method and nanotechnologies of producing sorbets differ from traditional ones by using cryogenic "shock" freezing and fine-dyspersated comminution as an innovation, which complex effect results in activation and extraction of hidden BAS from raw materials in the free form. The model experiments demonstrated that the new way and technologies result in transformation of a stiffener and structure creator of fruit pectin from the inactive form into the active soluble one. The obtained new types of sorbets are prepared by only natural ingredients (fruits, berries, vegetables) and don't contain different food supplements (stabilizers, stiffeners, emulsifiers, synthetic coloring agents and other) in their composition. It was established, that the new method allows not only to preserve vitamins and other BAS of the fresh vegetable raw materials completely, but also gives a possibility to extract hidden inactive forms (bound in nanocomplexes with biopolymers and mineral substances) from them into the free, easily-assimilated form. Thus the mass share of BAS in 
sorbets is 2,5...3,5 times more that in fresh fruits and vegetables. The effect of BAS increase is observed in all sorbets of different fruits, vegetables and berries in 2,5...3,5 times, depending on a raw material, its architectonics, chemical composition, type (Table 1). At the same time nanotechnologies of sorbets allowed to extract pectin substances that are in the fruit-vegetable raw materials in the inactive hidden form more completely in 3,0..5,0 times and to transform $70 \%$ of pectin substances in the soluble form (Table 1).

Table 1

The influence of cryogenic "shock" freezing and mechanolysis on BAS and pectin at getting one-component nanosorbets of fruits, vegetables, berries $(n=3, P \geq 0,95)$

\begin{tabular}{|c|c|c|c|c|c|c|c|c|}
\hline \multirow[b]{2}{*}{ Product } & \multicolumn{6}{|c|}{ Mass share, $\mathrm{mg}$ in $100 \mathrm{~g}$} & \multicolumn{2}{|c|}{ Mass share, $\%$} \\
\hline & $\begin{array}{l}\text { L-ascorbic } \\
\text { acid }\end{array}$ & $\begin{array}{l}\text { Phenol com- } \\
\text { pounds (by } \\
\text { chlorogenic } \\
\text { acid) }\end{array}$ & $\begin{array}{l}\text { Phenol com- } \\
\text { pounds (by } \\
\text { rutin) }\end{array}$ & $\begin{array}{c}\text { tanning } \\
\text { substances } \\
\text { (by tannin) }\end{array}$ & $\begin{array}{c}\beta \text {-caro- } \\
\text { tene }\end{array}$ & $\begin{array}{c}\text { Chloro- } \\
\text { phylls a } \\
\text { and b }\end{array}$ & $\begin{array}{l}\text { Anthocy- } \\
\text { ans }\end{array}$ & $\begin{array}{c}\text { Soluble } \\
\text { pectin }\end{array}$ \\
\hline Fresh apples & 55,0 & 580,1 & 160,3 & 380,2 & 0,1 & 0 & 0,2 & 1,5 \\
\hline Apple sorbet & 135,1 & 980,2 & 390,1 & 720,4 & 0,2 & 0 & 0,5 & 7,2 \\
\hline Fresh blackberry & 280,5 & 720,5 & 175,2 & 602,1 & 4,8 & 0 & 4,0 & 1,6 \\
\hline Sorbet of blackberry & 840,0 & 1330,0 & 280,1 & 1000,1 & 13,8 & 0 & 8,0 & 7,4 \\
\hline Fresh cherry & 68,1 & 670,1 & 142,1 & 420,1 & 0,2 & 0 & 2,5 & 1,4 \\
\hline Sorbet of cherry & 150,2 & 1102,0 & 280,1 & 740,2 & 0,3 & 0 & 5,0 & 6,5 \\
\hline Fresh apricot & 49,2 & 320,5 & 70,2 & 250,2 & 9,5 & 0 & 0 & 1,4 \\
\hline Sorbet of apricot & 140,1 & 560,4 & 120,6 & 480,4 & 32,5 & 0 & 0 & 7,2 \\
\hline Sea buckthorn & 95,2 & 570,2 & 95,1 & 420,0 & 11,5 & 0 & 0 & 1,2 \\
\hline Sorbet of sea buckthorn & 250,1 & 940,6 & 170,2 & 780,1 & 40,2 & 0 & 0 & 6,8 \\
\hline Freh pumpkin & 40,2 & 260,2 & 60,2 & 215,1 & 9,8 & 0 & 0 & 1,0 \\
\hline Sorbet of pumpkin & 108,1 & 480,6 & 105,2 & 401,2 & 41,2 & 0 & 0 & 4,5 \\
\hline Fresh spinach & 60,2 & 320,6 & 105,0 & 380,5 & 6,8 & 810,1 & 0 & 0,7 \\
\hline Sorbet of spinach & 178,6 & 560,0 & 175,2 & 720,1 & 21,0 & 1650,2 & 0 & 5,2 \\
\hline Frozen olives & 38,5 & 280,1 & 50,4 & 250,1 & 3,5 & 350,1 & 0 & 0,5 \\
\hline Sorbet of olives & 75,2 & 460,2 & 75,6 & 400,1 & 7,5 & 700,2 & 0 & 3,8 \\
\hline Fresh lemons & 80,2 & 101,1 & 75,0 & 300,4 & 0,2 & 0 & 0 & 1,8 \\
\hline Sorbet of lemons with zest & 200,1 & 180,2 & 135,1 & 560,2 & 0,4 & 0 & 0 & 7,8 \\
\hline
\end{tabular}

There were developed the recipes and studied the quality and content of BAS of three types of fruit-vegetable ice-cream of the different colors (green, yellow-green, pink) of chlorophyll-containing, carotene-containing and anthocyan-containing fruits, berries, vegetables. There was developed the wide assortment of healthy products «NatureSuperFood» - fruit-vegetable ice-cream-sorbet - green line, named «Green pleasure», «Green power», «Green pro», yellow-organge line - «Orange lime», «Carotene», «Caroton» and pink line, named «Purple», «Cherry», «Berries». The names of sorbets and sorbets themselves are at the stage of introduction in production. Natural coloring agents-BAS in the green line are chlorophylls of spinach and 
olives, in yellow-organe one - $\beta$-carotene and other carotenoids of aprocots, sea uckthorn and pumpkin, in the pink one - anthocyans of blackberries and cherries.

Based on the aforesaid results of the experimental studies, there was developed the new way of producing fruit-vegetable ice-cream-sorbets of fruits, vegetables, berries, differing from traditional ones by using the high freezing speed (from 1 to $20^{\circ} \mathrm{C} / \mathrm{min}$ ). At that the temperature in the cooling chamber is $-60 \ldots-100{ }^{\circ} \mathrm{C}$ and the final freezing temperature in the product must be lower than conventional one $-18^{\circ} \mathrm{C}$. At the same type the new method of producing sorbets includes using fine-dyspersated comminution of frozen mixtures of fruits berries and vegetables to particles, which size is tens times less than ones of traditional sorbets and frozen puree of fruit-vegetable raw materials. The offered fine-dyspersated fruit-vegetable mixtures are cut, packed and directed for tempering and refrigeratory storafe at temperature $-18{ }^{\circ} \mathrm{C}$.

There was studied the quality of new types of ice-cream-sorbets. They have an origical taste and smell of the natural product. At the same time sorbets differ from the initial raw materials that they are based on by the record content of natural BAS (L-ascorbic acid, phenol compounds, tanning substances, anthocyans, $\beta$-carotene, chlorophylls) and also prebiotic substances, included in the product in the soluble easily-assimilated form.

New types of fruit-vegetable ice-cream-sorbets are stored during 12 months without BAS losses that is provided by complete inactivation of oxidizing enzymes at their production.

The new method and nanotechnologies of healthy products «NatureSuperFood» - fruit-vegetable ice-cream-sorbets were probated under production conditions at enterprises of city Kharkiv (SPE “Krias plus”, LTD “ICF “Khladoprom”, LTD CUIC “Plus”).

\section{Conclusions}

For the first time in international practice there was developed the unique method of getting natural fruit-vegetable ice-cream in the sorbet form for healthy nutrition with the record content of BAS that favor strengthening of the immune system of the population and have detoxifying, antioxidant properties. New products have no analogues in the world.

The new method differs from traditional ones by using fine-dyspersated comminution and cryo-processing using liquid and gas-like nitrogen at processing fruits and vegetables, by high speeds of freezing and lower temperatures than ones, accepted in international practice (at $-50 \ldots-$ $100{ }^{\circ} \mathrm{C}$ ). At the same time the use of low-temperature fine-dyspersated comminution, accompanied by the processes of low-enzymatic catalysis of mechanolysis, allows to get sorbets in the nanosize form and to use the biological potential of natural raw materials as fully as possible.

The advantages of this work are in fact that at developing the new way of preparing sorbets, there was made a discovery that hidden forms of BAS and biopolymers were revealed in the natural raw materials.

It was established, that at this method of preparing sorbets the mass share of BAS extracted from the raw materials is $2,5 \ldots 3,5$ more than the one in the initially raw materials, and soluble pectin $-3,0 \ldots 5,0$ times.

The authors hope that the results, presented in the article, will have an essential practical value for both Ukrainian and international community, because the deficit of natural products is observed in the world, and each eighth dweller of the Earth suffers from hunger. At processing fruits and vegetables using traditional methods, the essential BAS losses are observed (from 20 to $80 \%$ ). At the same time the essential share of healing vegetable substances is assimilated by the human organism in $30 \ldots 50 \%$. That is there are essential losses of the biological potential both at processing and consumption that are hundreds millions of tons within the Planet.

\section{References}

[1] Marshall, R. T., Goff, H. D., Hartel, R. W. (2003). Ice Cream. Springer, 371. doi: https://doi.org/ 10.1007/978-1-4615-0163-3

[2] Clarke, C. (2015). The Science of the Ice Cream. Royal Society of Chemistry, 234.

[3] Pavliuk, R. Yu., Poharska, V. V., Radchenko, L. O., Pavliuk, V. A., Tauber, R. D., Tymofieieva, N. M. et. al. (2017). Novyi napriamok hlybokoi pererobky kharchovoi syrovyny. Kharkiv: Fakt, 380. 
[4] Topolska, K., Filipiak-Florkiewicz, A., Florkiewicz, A., Cieslik, E. (2016). Fructan stability in strawberry sorbets in dependence on their source and the period of storage. European Food Research and Technology, 243 (4), 701-709. doi: https://doi.org/10.1007/s00217-016-2783-0

[5] Yangilar, F. (2015). Effects of Green Banana Flour on Ice Cream's Physical, Chemical and Sensory Properties. Food Technology and Biotechnology, 53, 315-323. doi: https://doi.org/10.17113/ftb.53.03.15.3851

[6] De Souza Fernandes, D., Leonel, M., Del Bem, M. S., Mischan, M. M., Garcia, É. L., dos Santos, T. P. R. (2017). Cassava derivatives in ice cream formulations: effects on physicochemical, physical and sensory properties. Journal of Food Science and Technology, 54 (6), 1357-1367. doi: https://doi.org/10.1007/ s13197-017-2533-8

[7] Ozdemir, C., Arslaner, A., Ozdemir, S., Allahyari, M. (2015). The production of ice cream using stevia as a sweetener. Journal of Food Science and Technology, 52 (11), 7545-7548. doi: https://doi.org/ 10.1007/s13197-015-1784-5

[8] Innovation in ice cream manufacturing. Shaking a traditional dairy category. Available at: http:// www.allfoodexperts.com/innovation-in-ice-cream-manufacturing-shaking-a-traditional-dairy-category/

[9] Askew, K. VERU's "shock-freezing" tech creates ice cream with "more taste, less calories". Available at: https://www.foodnavigator.com/Article/2017/10/06/VERU-s-shock-freezing-tech-creates-icecream-with-more-taste-less-calories

[10] Pavlyuk, R., Pogarska, V., Kakadii, I., Pogarskiy, A., Stukonozhenko, T. (2017). Influence of the processes of steam-thermal cryogenic treatment and mechanolysis on biopolymers and biologically active substances in the course of obtaining health promoting nanoproducts. Eastern-European Journal of Enterprise Technologies, 6 (11 (90)), 41-47. doi: https://doi.org/10.15587/1729-4061.2017.117654

[11] Pavlyuk, R., Pogarska, V., Timofeyeva, N., Bilenko, L., Stukonozhenko, T. (2016). Exploring the processes of cryomechanodestruction and mechanochemistry when devising nano-technologies for the frozen carotenoid plant supplements. Eastern-European Journal of Enterprise Technologies, 6 (11 (84)), 39-46. doi: https://doi.org/10.15587/1729-4061.2016.86968

[12] Pavlyuk, R. Yu., Pohars'kiy, O. S., Kaplun, A. A., Losyeva, S. M. (2015). Developing the cryogenic freezing technology of chlorophyll-containing vegetables. Eastern-European Journal of Enterprise Technologies, 6 (10 (77)), 42-47. doi: https://doi.org/10.15587/1729-4061.2015.56111

[13] Pavlyuk, R., Pogarska, V., Mikhaylov, V., Bessarab, O., Radchenko, L., Pogarskiy, A. et. al. (2018). Development of a new method of storage and maximum separation of chlorophils from chlorophylcontaining vegetables at reception of healthfull nanoproducts. EUREKA: Life Sciences, 2, 47-54. doi: https:// doi.org/10.21303/2504-5695.2018.00616

[14] Pogarska, V., Pavlyuk, R., Timofeyeva, N., Bilenko, L., Stukonozhenko, T. (2016). Elaboration of new method of deep processing of caro-tene-containing raw materials into nanoadditives with the use of cryogenic freezing and fine-dispersed grinding. EUREKA: Life Sciences, 6, 37-43. doi: https:// doi.org/10.21303/2504-5695.2016.00251 